\title{
Women In The World Of Corporate Business: Looking At The Glass Ceiling
}

Priscilla Berry, Jacksonville University, USA

Tommy J. Franks, Lieutenant Colonel United States Army (Ret.)

\begin{abstract}
From a review of some of the literature and a brief compiling of statistics on women in positions of leadership and power, and with a quick look at the life and work of some contemporary women who have thought about and lived the life of corporate leadership, it is clear that women have made small progress into positions of power and influence. Research shows that this is true because they did not desire the positions of leadership, did not want to pay the price of the loneliness of leadership, or were derailed in some way by sex. A review of the timeline for the advances for women also shows the disconnect between what happens in legislation or social opinion and what really happens to the plight of women in the halls of power. Research indicates the alternative for women seeking positions of power in the corporate structure is as follows: Some women... who are the best qualified for leadership...leave the corporate ranks and never return. Some decide to become entrepreneurs. Some decide on other upward mobility enterprises. This paucity of women in the Boardroom and at the helm of corporate power definitely accounts for the lack of soul, ethics, and the general quandary in corporate America. The dilemma that leaders are now facing is: What happened here, as evidence by corporate scandals and the fall of Wall Street, where do we go, and what do we do now?

It is the focus of this paper to show that the greatest deterioration of the corporate structure is caused by the following: Not including and/or promoting women into the ranks of leadership...real policy making power...not providing a female friendly environment for women, not setting up legitimate and ongoing mentoring systems for women, not recognizing the different, but significant, voice of knowledge that women bring to the table.
\end{abstract}

Keywords: corporate women, salary parity, glass ceiling, sticky floor, leadership, women in power

\section{INTRODUCTION}

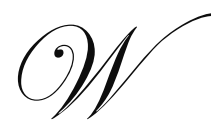

hile business organizations say they are struggling to hold on to their best and brightest women, the persistence of the glass ceiling makes this all talk for the women who walk in the halls of power. When we look at the lives of women and the statistics of those who attempted the journey to power, we see that dismantling the glass ceiling requires an accurate understanding of the obvious and subtle barriers to advancement faced by women... and the strategies that both women and the corporations must adopt to overcome these barriers. By "glass ceiling", we mean the invisible artificial barriers that block women from senior executive jobs. The "sticky floor" is another problem. This term describes the forces that keep women stuck at the bottom of the economic pyramid.

\section{FIRST WORDS}

A large-scale, national survey in 1998 of Fortune 1000 CEOs and the highest-ranking women in their companies cited key career strategies women used...in their rise within the corporate structure. This survey identified some of the barriers to advancement (Ragins, 1998). There is an obvious disconnect in what the male power structure assumes, admits, or answers when talking about women in their corporate environment. 
The key finding of the study was the total disconnect in the perceptions of chief executive officers and the high-ranking women in their firms. The Fortune 1000 CEOs had perceptions which differed widely with the females surveyed in both the organizational and environmental barriers. The company's report card and the women's report card were far from harmonious.

\section{THE RATIONALE}

Women have particular qualities that can be vital to the survival and success of any business, but they bring a unique and new paradigm to corporations willing to be inclusive. Those who work for businesses need to be aware of the incredible dilemmas and conflicts that affect women.

Bottom-line: Statistics reveal the concept of the unlevel playing field. The paradigm takes for granted that "men" somehow have the advantage when it comes to management abilities. Rather than assume that both men and women should have the same opportunity, the pervasiveness of the myth of masculine ethics is always reviewed... with men being more effective with ethical organizational behavior. This is truly a myth and fairy tale.

\section{THE TIMELINE}

When I was graduating from high school in 1964, the Civil Rights Act was passed making it illegal for employers to discriminate on the basis of sex. That did not stop the HR director of Heinz companies in Jacksonville, Florida from saying to me: "I just can't hire you, honey, even though you are more than qualified. If I put you on the floor with all those men, I would never get any work done." I went to college rather than seek employment. Betty Friedan had published the Feminine Mystique in 1963, and we thought the world would change. In 1968 women protested the Miss American Pageant in Atlantic City. In 1972, Title IX was passed which mandated that the same money in college athletics be equal to men as well as women. More women were now available for the world of sports entertainment, but possibly some good came from this endeavor. In 1978, the pregnancy discrimination act passed which protected women, but on the basis, that it was the same as a temporary handicap. Yeah, boy, right about that one! In 1981, Sandra O'Connor was elected to the Supreme Court. This was extremely vital and important. In 1984 Geraldine Ferraro was the Vice Presidential nominee. She still has face power today. In 1986, sexual discrimination was determined by the Supreme Court to be illegal job discrimination, but who would protest? When my daughter was born in 1991, Tailhook happened and 80 Navy and Marine women are allegedly molested at a convention in Las Vegas. (Of course, they asked for it!) In addition, the year of my daughter's birth, Anita Hill accused Clarence Thomas of sexual harassment. I guess it showed that we were making some progress when the US Department of Labor established The Glass Ceiling Commission in 1991. In 1992, record numbers of women run for public office. In 1996, the case of the Smith Barney Boom, Boom Room reached the airwaves and the sex scandals became legendary throughout the financial services sector with Smith Barney paying out an estimated \$245 million in claims and others followed. Males were accused for horrible sexual abuse. Nancy Pelosi was elected Speaker of the House in 2007 and Hillary Clinton has recently been installed as the new Secretary of State. In regards to Secretary Clinton, it seems that Bill Clinton's charm was partly responsible for Hillary's popularity across America rather than her own wit and wisdom. In addition, no one has bothered to state for the camera that her husband disgraced an entire nation with possible impeachment over his affair with a White House intern as he implopred the nation to contemplate with him the meaning of "is" and made a forever-clear distinction between oral sex and sexual intercourse. Did the entire United States of American and the world need to "see" this type of thing? My friends say, "Well, this kind of behavior has always been the norm with men in power." Ah, yes, of course, this explains it all so completely. We had a candidate for the Republican Vice Presidency, Sarah Palin, a woman who may very well represent the new face of feminism when she emerges again in 2012. Her choice of husband who is so completely viral and domestic is yet another dimension for the female who would be in charge. Her unvarnished and untraditional path to leadership demanding that she can be a Mom to five children and still lead with competency is yet to be proven. We are waiting to see on his one. It does add to the discussion certainly.

\section{THE BIG PICTURE}

Although the number of women in middle management has grown quite rapidly in the last two decades, the number of female CEOs in large corporations remains extremely low. Why have women not risen to the top? They 
have line experience, incredible people skills, style, and socialization. While the 90's saw some advances for women, this was probably only token gestures and a reactionary response to the blatant egregious behavior of males in business in this time period and the "in-your-face type" of journalism that has been allowed far too long.

The numbers and ranks of women in power positions have actually declined. The Dingell-Maloney report in January 2002 using data from the U.S. General Accounting Office looked at ten industries including communications, public administration and business and repair services. Entertainment, education, financial and other professional employment were also included. The report concluded that the advances of women over the past five years have gone backwards (Baue, 2002). The report states: "True parity in the workplace remains a distant promise rather than a coming reality." Their research showed that...in seven of ten industries, the pay gap actually widened. The period of time for the research... a time of prosperity...causes even more alarm given the current economic environment. The seven industries that showed the gap were all private and the ones that remained stable were public or government controlled (Baue, 2002).

Furthermore, never forget the old boy network and tokenism at the top. Leadership styles at the top of organizations are typically quiet different for most women. In addition, most men have not yet accepted the leadership of brilliant women nor do they have an understanding of the communication styles of women. Women, who are empowered in leadership roles, often pose a threat and a negative challenge to the average male executive.

Since the mid-1970s, women have entered the work force in increasing numbers. Now, for the first time, organizations employ a significant number of women who have reached midlife and midcareer. These women provide a model of high-level performance that can offer broad experiences for the wider population facing midlife issues. Although many organizations have attempted to respond to the needs of working women, the most common programs likely are inadequate for these midlife women. These women bring personal maturity, significant professional experience, and a desire for new challenges to any corporation. They have significantly different needs from their younger female counterparts and their male midlife contemporaries. They have coped with the challenges of midlife in ways that have changed their styles and perspective. Their roles and performance have modified their job and work environment. Organizations that wish to retain these talented women and address female issues for the aging workforce should focus on changing human resource policies and practices and creating a culture to support and effectively use their talents and motivate their continued achievement.

\section{LEADERSHIP STYLES}

The one recurring theme suggests that researchers on women in leadership often face real issues, which also include experienced women managers and leaders. Sometimes, women come out of academic cultures, which have been significantly shaped by a male-dominated history. Males doing gender research seem to pursue issues, which have dubious legitimacy when it comes to research. Therefore, many recurring research questions about women in organizations are shaped by the framings of the world of men, which already encode gender-power assumptions. This influences much of the gender-related research. It holds so much power because management has become heavily saturated with idealizations of masculinity. Someone once said, "Think Manager...Think Male".

The power of the male is the norm. Early on women in management sought to prove women the same as men to gain equality. It was largely successful in showing that women could display similar leadership styles, motivations for working and career aspirations to men. The reality is that the leadership style of women is quiet different that the male counterparts. Women are much more collaborative in management styles than men and listen more than men and are more responsive to coworkers than men. Men seek to gain power through the more dominate form of top down communication. A more recent trend suggests that women favor more interactive management styles than do male colleagues.

Julia Gerberding (Head of the CDC...one of 11 federal agencies in charge of public health) has said that she favors the collaborative style of leadership and that she will not engage in turf war. It is important to her to step back from differencing viewpoints and find common ground. Her success with this leadership style can be seen as she testified before Congress in the latest waves of public health challenges, such as Katrina, the anthrax case, and the diagnosed tubercular patient who slipped through security and flew on a public air carrier. Ms. Gerberding was able to 
assemble a team of people who supplied the required information to the public and congress. With great care, she articulated the actions and the position of her agency.

Carly Fiorina, the controversial CEO of Hewlett Packard, had a unique leadership style. She was decisive and performed more like a man and received criticism for her overly direct methods in achieving success for HP. In short, she got the job done, but members of the Board did not like her style, or her. If Carly were a man, probably no one would have noticed or complained. Men, especially men over 50, are not comfortable with women in power and certainly not a woman who would question their comments and actions as Carly did for some of her Board Members who leaked confidential information from Board Meeting. She remains a powerful woman whose leadership style will serve her well in its next venue and possibly more men will be prepared. They will know what they are asking for, when they get it!

Meg Whitman is yet another example of a leadership style that essentially created e-bay, the most successful company in the shortest amount of time in the history of capitalism. She took a small company that was just a fledgling and turned it into a company that represents the future shape and philosophy of equalitarianism and of global business. Meg has a more casual style of leadership and believes in the team concept in extreme. If you are not one with your staff and one with your customers, you are not on target for leadership, according to Meg. Leaving e-bay after 10 years as CEO, Meg said that the company, as with all companies, needs fresh eyes. The truth is that the world of financial analysts who have insisted that a company has to grow at $25-30 \%$ to be of interest to the world of speculation is probably over. In other words, Wall Street has destroyed companies by pressuring the good one and solid ones to turn over leadership like football teams turn over coaches. This world of noxious speculation seems to have all the pressure of the box office movie openings without as much promise. This is business and not football and Carly and Meg will go on to lead, manage, and motivate significant institutions in the future with their leadership in tact. Both Meg and Carly have been mentioned as a possible candidate on the short list for governor of California.

Is it possible to escape a man's world? Perhaps not yet, the male-as-norm still seems such a pervasive and insidious influence on thinking and valuing. Many taken-for-granted reference points in the organizational world are founded on a male-dominated history. Attributing employment dominance over other areas of life and privileging hierarchic success above other forms of achievement are key instances.

\section{WOMEN LEAVING THE RANKS}

Many successful women managers are 'leaving' employment because of the Gender Challenges for Women in the World of Business. They are seeking and finding success in the entrepreneurial world.

Words for leaving when attributed to women...such as 'quitting' and 'attrition'...often carry connotations of being unable to cope... which is simply not true.

Women entrepreneurs are growing rapidly. An important trend to note is that more women than ever before are becoming employers and running their own businesses worldwide...38\% of the entrepreneur firms in the United States are run by women.

Latin American region, micro-businesses and self-employment are a major source of employment and income for women... 30 to $60 \%$ of all micro-businesses of the region are operated by women. Supporting women to gain more economic power through running their own business and

The United States National Foundation for Women Business Owners indicates that firms owned by women around the world can account for one-quarter to one-third of businesses in the formal sector and have an even stronger presence in the informal sector. A UN study reports that in the Latin American region, micro-businesses and selfemployment are a major source of employment and income for women...30 to $60 \%$ of all micro-businesses of the region are operated by women. Supporting women to gain more economic power through running their own business and employing others may well be a key strategy for reducing gender inequalities in our current century. So what can be done in the United States to speed up women's entry to the highest echelons of decision-making? 


\section{GENDER FORCE}

Managers often face challenges about how they deal with apparent differences between men and women...specifically targeted as social groups. The analyses are evocative, appealing, and often useful. It suggests that men are more likely to be preoccupied with issues of hierarchy, status, and women with issues of equal participation and relationship. Whilst arguing for the possibility of balance is potentially conceivable, it will often prove unconvincing. Issues of power play themselves out around gender, especially as they are being considered and acknowledged. Furthermore, the continuing pervasiveness of male-as-norm makes some territories of experience dangerous to explore. Mentioning menstruation, menopause, and health, is likely to invoke anger and irritation because it insinuates that women are vulnerable and potentially deficient.

There is no doubt that significant progress has been achieved in furthering the cause of gender equality in the labor market over recent decades. Women have been moving steadily into occupations, professions and managerial jobs previously reserved for men. Their access to education and training continues to improve, providing many with the necessary qualifications to aspire to jobs in senior management. Governments, businesses, trade unions, and women's organizations have devoted much thought and energy to overcoming the attitudinal and institutional discrimination that bars women from certain jobs and hinders their career development, while the commitment to fight gender discrimination is renewed periodically at international conferences.

Yet, many of the results fall short of expectations. Women are still concentrated in the most precarious forms of work throughout the world and breaking through the "glass ceiling" still appears elusive for all but a select few. For women who also experience race discrimination, the barrier to top jobs seems to be made of unbreakable Plexiglas.

Research and analysis suggest that discrimination is greatest where the most power is exercised. The higher one goes, the larger the gender gap:

- Women hold 1 to $3 \%$ of top executive jobs in the largest corporations worldwide. For women who also experience race discrimination, the percentage is even less.

- $\quad$ Only 8 countries have a woman head of state; 21 countries have a deputy head.

- $\quad$ Only $13.4 \%$ of the world's Parliamentarians are women.

- Only $1 \%$ of trade union leaders are women, though women are almost $40 \%$ of their membership globally.

Data shows that women have the qualifications and work experience to take on responsibilities at the highest level. However, the challenge is the slow pace in achieving a critical mass of women in top jobs with power.

The obstacles can often be traced to the way work itself is organized and the formidable challenges women and men face in trying to reconcile work and family commitments...especially with the increased pressures and insecurities in today's global economy.

The result is persistent occupational segregation...men's jobs and women's jobs. It is unjust and inefficient. Even countries with strong track records for promoting gender equality still have strong degrees of occupational segregation. Compounding the problem, so-called women's jobs are often assigned a lower market value. Even in women-dominated fields, such as in health and education, men usually occupy the "more skilled" and "responsible" positions.

Explanations for why women have not risen to the top are varied, including lack of line experience, inadequate career opportunities, gender differences in linguistic styles and socialization, gender-based stereotypes, the old boy network at the top, and tokenism. Alternative explanations are also presented and analyzed, such as differences between female leadership styles and the type of leadership style expected at the top of organizations, feminist explanations for the underrepresentation of women in top management positions, and the possibility that the most talented women in business often avoid corporate life in favor of entrepreneurial careers and better-paid positions.

Developments in job evaluation methodologies, however, have demonstrated that many jobs occupied by women in fact require levels of skills, responsibilities and complexity similar to the higher paid jobs held by men. The 
pay gap between men and women workers is still cause for concern. Pay differentials persist in all countries ranging from 10 to 30 percentage points.

The management job gap and the pay gap are two obvious manifestations of the different ways males and females spend time on work and family matters. Studies show that women, on average, work longer hours than men in nearly every country. In addition, women continue to work overtime without being paid.

Various surveys as of late...indicate that women hold a meager share of the top executive jobs in companies around the globe...1.3 \% in Australia, $2 \%$ in France, 3\% in Germany, 3\% in Brazil, and 3.6\% in the United Kingdom. Some breakthrough has been achieved in the United States with women obtaining 5.1\% of chief executive positions in the 500 largest companies in America.

Women have been moving steadily into a wider range of professional jobs and gradually swelling the ranks of lower and middle management in recent decades. International Labor Organization (ILO) data shows that in nearly half of the 41 countries for which data was available for 1999, women typically held between 20 and 30 per cent of all legislative, senior official and managerial positions. In 16 of these countries women held between 31 and 39 per cent of such jobs. Countries in Central and Eastern Europe such as Estonia, Hungary, Latvia, Lithuania, Poland, the Russian Federation and the Ukraine are among the highest ranking for women in management, along with other industrialized countries such as Canada, Ireland, New Zealand and the United Kingdom. The United States also appears in this league under a data category that includes administrative workers.

The proportion of women in administrative and managerial positions seems to be quite significant in a number of developing countries such as Colombia, Bermuda, Philippines, Honduras, and Venezuela. However, most of the working women in these countries are well educated and prepared for professional occupations and their skills are in demand. In addition, managerial women in developing countries often rely on extended family arrangements and the availability of inexpensive domestic assistance for childcare and household assistance. The Mexican government recently reported that women held $12 \%$ of executive management positions as presidents, director-generals and general managers in the public and private sectors. Even though this has not been verified, it seems viable.

In the financial sector, despite the fact that women have made some inroads in senior management in recent years, they are not breaking through to the top positions. A survey of European banks showed increases in the proportion of women in executive positions except at the board level, which remained static at around 5\%.

At the London Stock Exchange, one third of the board and half the executive directors are women. At the Paris Stock Exchange, 33\% of the directors are women. A notable exception for top jobs in recent years has been the appointment of a woman as President of the Central Bank of Finland and recently a woman was chosen to head the London Stock Exchange.

A significant problem contributing to the difficulties facing women to reach the top seems to be the fact that few senior women are in the so-called "line" positions that involve profit-and-loss or revenue generating responsibilities that are critical for advancement to the highest levels. Currently, men still hold about $90 \%$ of line jobs in the United States. Similarly, in Canada, men hold about $89 \%$ of line jobs.

This is a reflection of so called "glass walls" where women managers are concentrated in certain sectors. Women executives, administrators and managers in the United States are more likely than men to be active in the service, insurance, real estate, public administration and finance sectors, with $42 \%$ of women administrative and managerial employees being in the services sector compared with $30 \%$ of men.

Do we have "Pay Gaps in Management"? Certainly. Inequality in access to certain types of management jobs leads to pay gaps in wages for men and women. Furthermore, while rates of pay may be similar, actual earnings vary because of different salary packages offered to managers, which provide various fringe benefits and access to certain schemes for boosting bonuses. Despite women managers often being more qualified than their male counterparts, their lower earnings reflect differences in seniority and the concentration of women in lower paid managerial sub-groups. In the United Kingdom, a company survey showed a 15\% difference between the average female and the average male 
manager. At the director level, the gender gap was even greater at $42 \%$. Surveys in other countries during recent years reveal similar gaps, 35\% less for women managers in Finland, 50\% less in Brazil, $43 \%$ less in Uruguay, 12\% less in Australia, and $16 \%$ less in the United States.

\section{THE WAY FORWARD}

First, we must believe that faster progress is possible. In the United States, the number of women in the Fortune 500 executive management positions has more than doubled in the past three years...currently $5.1 \%$. We must continue to explain how and why gender equality is important for economic growth and the welfare of our nation. We will never be healed or whole until we have equal representation in the numbers of women with parity, in reality and in spirit present in the corporate world. To be effective, organizations and firms will need to have a balanced mix of socalled "masculine" and "feminine" attributes at all levels.

Meaningful change requires that we do the following:

- $\quad$ Diversify occupations for women and men

- $\quad$ Foster greater sharing of family responsibilities

- Innovate with proven human resources and budget strategies

- $\quad$ Cultivate and nurture women's entrepreneurial talents

- $\quad$ Require sensitivity training that focuses on gender understanding

For companies and organizations to remain competitive, we cannot afford to miss our on women's talent. It is not only the right thing to do; it is the smart thing to do! Education has proved to be a powerful tool in improving the status of women and globally wide women's enrolment rates at the post secondary level. In the regions of the Americas, Europe, and other countries, more women than men are enrolled at this level. While gender differences in education persist, particularly in occupational choices, women are moving steadily into professional and technical fields previously reserved for men.

For example, more young women are studying mathematics and technological sciences. Engineering, however, is still a difficult area for women, but there has been some progress. Over the last decade, the percentage of enrollments in engineering for women has increased to $19 \%$ in several countries.

Fully utilizing women's potential requires a commitment to overcome the persistent occupational segregation in the labor market. The implementation of affirmative action and awareness-raising campaigns can help counter gender discriminatory attitudes. A key factor in improving gender equality in the labor market is the issue of reconciling work and family. Supportive work environments and flexible working hours are increasingly in demand from both men and women. Many companies and organizations are taking steps to ensure that human resource management reflects these needs and provides career and succession planning services, formal systems for recruitment and clear job descriptions. Positive action, equal opportunity policies, prevention of sexual harassment policies, diversity management, mentoring, and the tracking and monitoring of the progress of both men and women have been identified as useful ways to level the playing field and improve gender equality in training, recruitment, and promotion at the organizational level.

Only active promotion of gender equality in all areas of education and employment by governments, civil societies, and trade unions can guarantee gender equality at the highest levels of management, especially in the public and private sectors. Heretofore, managerial commitment has been shown to be critical to enhance successful equality measures. Furthermore, equal opportunities and positive action cannot be confined to individual organizations or business initiatives.

One of the most critical strategies is to support women employees at an early stage in visible and challenging assignments. This will often ensure that they will obtain experience in a wide range of corporate operations. This will equip them to become managers and executives later in their careers. Commitment of top management is imperative for the success of these policies. Such commitment can only spring from an awareness that competitive companies cannot afford to miss out women's talent. 
Since its foundation, the International Labor Organization (ILO) has made a critical contribution to the promotion of equality between men and women in the world of work. They have addressed equality issues such as discrimination, safety, equal pay for equal work, and corporate responsibilities. Today, gender equality is their goal and catalyst to achieve their core vision: decent work for women and men in conditions of freedom, equity, security and dignity.

The ILO is also keenly aware of the need for the availability of a greater range of labor market statistics desegregated by sex. It works intensively on standardizing the collection and dissemination of comparative data on work and employment based on the development of gender- sensitive indicators. The ILO has been persistent in urging governments to analyze the national situation to determine the extent and nature of the pay gap by addressing the equal pay issue.

Enhancing women's role in decision-making and management is key to successfully addressing inequalities in the labor market. By working together with governments, employers' organizations, trade unions, civil societies, and the UN family, the International Labor Organization intends to continue to play a pivotal role in dismantling the socalled glass ceiling. The ILO champions gender equality at work to the highest level of decision-making in global corporations.

Surprisingly, not a whole lot has been written about gender and business performance. Research indicates that only a small number of serious studies of substance have been published on this subject and not enough by women authors. Analyses suggest that the relationship between gender and business performance is complex. As a reminder, gender still appears to be a significant determinant even during the $2{ }^{\text {st }}$ Century; bridging this inequity will be a beginning step to creating the culture of sustainability that every corporation, domestic and international, must embrace.

My daughter graduates from high school in May 2009, some things have changed, many have not! I want so much to tell her she can be whatever she wants to be and that the Glass Ceiling has gone away.

Note that on the eve of this writing Sharon W. Watkins, General Minister and President of the Christian Church, both reverend and doctor, will deliver the first ever sermon by a woman at the $56^{\text {th }}$ annual Prayer Service as part of the 2009 Inaugural Ceremonies for President Obama at the National Cathedral in Washington, D.C. At least now maybe, if nothing else, the men will let us lead the prayer! Also, of note is the signing of the Fair Pay Act of 2009 or the Lilly Ledbetter legislation that requires equal pay for equal work. These laws have been in place for a long time, and we can see if the stroke of a pen will make a difference going forward or if, as historically is the case, we will still have to wait!

\section{AUTHOR INFORMATION}

Dr. Priscilla Berry, currently an Assistant Professor of Communications in the Davis College of Business at Jacksonville University, has a private communications consulting practice: Berry and Associates, which provides businesses with specialized programs to assist with cultural transformation and leadership development, solving internal and public communication challenges. She is a graduate of the University of Mississippi with degrees in English, Literature, and Humanities. She began her career in academia as a professor of literature and writing, but was recruited by local corporations to work on the development and facilitation of communication systems. Selected Corporate Clients include: Communications Planning Corp, Children's Haven, Americall, LDC, DuPont, Interline (U.S. West), Duval County School Board, CSX, the Jacksonville Symphony, and the Army Corp of Engineers. She was a guest professor for a semester at the University of Caen in France where she lectured to international postgraduates on Doing Business in a Global Economy.

Dr. Franks has served as Adjunct Professor for the US Army Command \& General Staff College, Ft. Leavenworth, KS. He has also served as a Military Academy Liaison Officer for West Point, NY. He has served the US Military and US Government for 37 years. His main focus for the past decade has been Communications and Intelligence for the US Government which included assignments at the National Security Agency, Washington, DC and US Army HQ, Intelligence Security Command, Ft Belvoir, VA. In 1980, Dr. Franks received his Ph.D. in psychology (Marriage and Family Counseling). He is currently retired and resides in Lakeland, FL. 


\section{REFERENCES}

1. Baue, W. (April 19, 2002). Glass Ceilings Hardens Instead of Shattering for Women in the U.S. and U.K. Retrieved June 17, 2008 from http://www.socialfunds.com/news/prig.cgi?sfArticleId=

2. Baer, J. (1991). Women's Rights in the U.S.A.: Policy Debates and Gender Roles. Pacific Grove: Brooks/Cole Publishing Company.

3. DeCrow, K. (1974). Sexist Justice. New York: Random House.

4. Dollarhide, M.C. (March, 1999). From the "Boom Boom Room" to Wall Street: The High Price for Locker Room Antics In the Financial Services Industry. Retrieved January 13, 2009, from http://library.findlaw.com/1999/Mar/1/127108.html

5. $\quad$ Kanowitz, L. (1981).Equal Rights: The Male Stake. Albuquerque: University of New Mexico Press.

6. Oakley, J.G. (2000). Gender-based Barriers to Senior Management Positions: Understanding the Scarcity of Female CEOs. Journal of Business Ethics, 27(4), 321-334.

7. Ragins, B.R., Mattis, M., \& Townsend, B. (1998). Gender Gap in the Executive Suite: CEOs and Female Executives Report on Breaking the Glass Ceiling. Academy of Management Executives, 12 (1), 28-42.

8. Rubin, Harriet. (April 2008). Sexism. Conde Naste. Retrieved January 19, 2009, from http://www.portfolio.com/interactive-features/2008/03/Sexism-Gender-Wars.

9. Wirth, L. (2001). Breaking Through the Glass Ceiling. Geneva: International Labor Organization. 


\section{NOTES}

